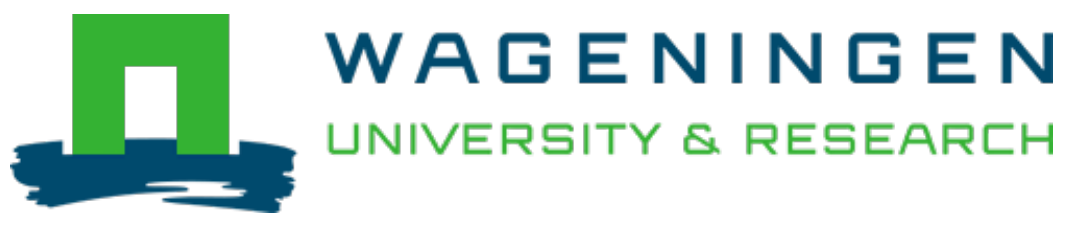

\title{
Coordinating food quality : How do quality standards influence contract arrangements? A study on Uruguayan food supply chains
}

\author{
Supply Chain Management : an International Journal \\ Groot-Kormelinck, Annemarie; Trienekens, Jacques; Bijman, Jos \\ https://doi.org/10.1108/SCM-02-2020-0087
}

This article is made publicly available in the institutional repository of Wageningen University and Research, under the terms of article $25 \mathrm{fa}$ of the Dutch Copyright Act, also known as the Amendment Taverne. This has been done with explicit consent by the author.

Article 25 fa states that the author of a short scientific work funded either wholly or partially by Dutch public funds is entitled to make that work publicly available for no consideration following a reasonable period of time after the work was first published, provided that clear reference is made to the source of the first publication of the work.

This publication is distributed under The Association of Universities in the Netherlands (VSNU) 'Article $25 \mathrm{fa}$ implementation' project. In this project research outputs of researchers employed by Dutch Universities that comply with the legal requirements of Article 25fa of the Dutch Copyright Act are distributed online and free of cost or other barriers in institutional repositories. Research outputs are distributed six months after their first online publication in the original published version and with proper attribution to the source of the original publication.

You are permitted to download and use the publication for personal purposes. All rights remain with the author(s) and / or copyright owner(s) of this work. Any use of the publication or parts of it other than authorised under article $25 \mathrm{fa}$ of the Dutch Copyright act is prohibited. Wageningen University \& Research and the author(s) of this publication shall not be held responsible or liable for any damages resulting from your (re)use of this publication.

For questions regarding the public availability of this article please contact openscience.library@wur.nl 


\title{
Coordinating food quality: How do quality standards influence contract arrangements? A study on Uruguayan food supply chains
}

\author{
Annemarie Groot-Kormelinck, facques Trienekens and fos Bijman \\ Business Management and Organization, Wageningen University and Research, Wageningen, The Netherlands
}

\begin{abstract}
Purpose - The aim of this paper is to study the influence of quality standards on contract arrangements in food supply chains.

Design/methodology/approach - A qualitative double case study was conducted on the dairy and citrus sectors in Uruguay. A transaction cost theoretical framework was used. All current public and private quality standards applied by processors were studied in relation to contract arrangements between processors and upstream producers as well as downstream buyers for each sector.

Findings - Quality standards complement contract arrangements for upstream transactions, leading to hierarchy-type contract arrangements. Quality standards substitute contract arrangements for downstream transactions, leading to market- or hybrid-type contract arrangements.

Research limitations/implications - Longitudinal studies that measure changes in contract arrangements over time are recommended.

Practical implications - Supply chain actors can reduce transaction costs by aligning quality standards with appropriate contract arrangements further supported by public instruments.

Originality/value - Quality standards have differential influence on underlying transaction characteristics, and therefore on contract arrangements, depending on the location of the transaction in the supply chain.
\end{abstract}

Keywords Quality standards, Contract arrangements, Transaction cost economics, Food quality management, Supply chain governance, Uruguay, governance, supply-chain management, food industry, quality management, contracts, transaction cost theory

Paper type Research paper

\section{Introduction}

Coordinating food quality throughout supply chains has become more important over the past decades (Lee et al., 2012). With globalizing supply chains, food products travel across multiple continents - leading to greater food safety risks. Moreover, the prevalence of food safety scandals has caused more public anxiety (Pouliot and Wang, 2018). In addition, consumers are increasingly demanding quality of the food production process, such as assurance of good social practices, animal welfare and environmental management. Food quality has thereby become multidimensional (Goodhue, 2011), and there has been a shift in interest from observable toward nonobservable quality attributes, which implies additional quality uncertainty for buyers and increased interdependencies among supply chain actors (Raynaud et al., 2009).

Quality standards are external institutions to coordinate food quality in supply chains. Quality standards are rules of classification and measurement established by recognized and consistent use or by regulation (Giovannucci and Reardon, 2001). In recent decades, mandatory public standards, such as (inter)national laws and regulations have tightened

The current issue and full text archive of this journal is available on Emerald Insight at: https://www.emerald.com/insight/1359-8546.htm

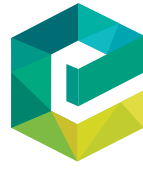

Supply Chain Management: An International Journal (C) Emerald Publishing Limited [ISSN 1359-8546] [DOI 10.1108/SCM-02-2020-0087] requirements on food safety, and widened in focus by including production process characteristics (Trienekens and Zuurbier, 2008). Besides, private standards, such as GlobalGap or ISO, have proliferated, both in scope and scale. Such standards are established by individual or collective private actors, and adoption by supply chain actors can be voluntary or demanded by retailers to access a certain market (Henson and Humphrey, 2010). Private standards may be established to complement inadequate public standards, reduce transaction costs by standardizing products and processes, protect brand capital and defend companies' reputation and create competitive advantage through product differentiation (Lee et al., 2012). Quality standards increase vertical coordination throughout the supply chain by setting quality requirements and controlling compliance at multiple supply chain nodes, often through third-party audits (Trienekens et al., 2012).

A broad range of studies have emerged on the relation between quality standards and food supply chain governance. These studies focus on reasons for supply chain actors to adopt quality standards (Stranieri et al., 2017), their preferred

\section{Declaration of interest: None.}

Acknowledgement of funding resources: Funding comes from the Wageningen University and Research internal funds (Wageningen School of Social Sciences fund).

Received 27 February 2020

Revised 7 July 2020

5 October 2020

12 October 2020

Accepted 18 October 2020 
enforcement mechanisms (van der Merwe et al., 2019), quality performance (López-Bayón et al., 2018) and quality control (Jraisat and Sawalha, 2013). A specific field of studies analyzes how quality standards affect bilateral contract arrangements between supply chain actors (Raynaud et al., 2005; Banterle and Stranieri, 2008; Wever et al., 2010; Ghozzi et al., 2016, 2018; Fernández-Barcala et al., 2017). Transaction cost economics (TCE) is the most used theory in these studies, explaining the choice for a contract arrangement based on the need of supply chain actors to keep transaction costs as low as possible (Williamson, 1991). Contract arrangements vary from markets (little control) to hierarchies (high control), with hybrid types in between (Williamson, 2002).

Quality standards are considered to influence the choice of contract arrangement by affecting the transaction characteristics (Young and Hobbs, 2002). To reach quality coordination, some studies claim that quality standards lead to additional quality coordination in hierarchy-type contract arrangements (Banterle and Stranieri, 2008; Ghozzi et al., 2018), whereas others find standards to lead to reduced quality coordination in market-type contract arrangements (Raynaud et al., 2005; Fernández-Barcala et al., 2017). Thus, existing studies yield mixed results on the influence of quality standards on contract arrangements. Besides, these studies focus on how the introduction of a single quality standard affects contract arrangements in a supply chain. A knowledge gap exists on the influence of quality standards on contract arrangements, when combinations of public and private quality standards are taken into account.

This paper aims to fill this gap by providing insights on how quality standards affect contract arrangements in food supply chains. Primary and secondary data were collected in a double case study on the dairy and citrus sectors in Uruguay. For each sector, quality standards and contract arrangements were studied for transactions that processors - the focal supply chain company - have with upstream producers (T1) and with downstream buyers in three supply chains (T2, T3 and T4). All current public and private standards applied by processors have been included - a total of 60 public and 15 private standards. Quality standards and contract arrangements are compared on coordination and control of quality requirements, classified into three attributes: sensory, safety and process quality. This study takes a broad, qualitative approach in studying how combinations of public and private quality standards applied by supply chain actors affect contract arrangements for different transactions within and across supply chains.

We aim to make four contributions. First, to our knowledge, this is the first attempt to study all public and private quality standards present in a case. In this way, our approach yields more realistic insights in the complex coordination of food quality in supply chains, as compared to existing studies on single quality standards (Ghozzi et al., 2016; FernándezBarcala et al., 2017). Second, studying four transactions in each case allows analysis on how quality standards affect contract arrangements within and across supply chains. Such design goes beyond studies on dyadic transactions (Raynaud et al., 2005; Banterle and Stranieri, 2008) - and contributes to increased calls for addressing interdependencies among multiple supply chain transactions (Mena et al., 2013; Kataike et al., 2019).
A third contribution is that we add insights on the application of TCE in supply chain management by showing how quality standards affect contract arrangements by changing the transaction characteristics. Our results advance studies that attribute contract arrangements to a quality standard without explaining how the effects come about (Wever et al., 2010; Trienekens and Wognum, 2013). Finally, although most studies focus on highly-specialized supply chains in Europe, the context of Uruguay provides useful insights on how supply chain actors in transition countries combine contract arrangements with multiple public and private quality standards. Such insights contribute to the increasing body of literature that focuses on how farmers in developing and transition countries can participate in high-quality food supply chains (Jaffee et al., 2011; Groot-Kormelinck and Bijman, 2016).

The remainder of this paper is organized as follows: Section 2 presents the literature review, including the theoretical basis, conceptual framework and a review of empirical studies. Section 3 contains the methods, followed by the descriptive results in Section 4. Section 5 analyzes and discusses the findings. Finally, Section 6 provides the policy and managerial implications, limitations, directions for further research, contributions and concluding remarks.

\section{Literature review}

\subsection{Contract arrangements}

Contract arrangements, sometimes called "governance structures," refer to the organization of transactions within supply chains. TCE predicts that choices for a contract arrangement are determined by transaction characteristics, mainly uncertainty and asset specificity (Williamson, 1985). Uncertainty refers to the inability of transaction actors to measure the outcomes of a transaction, such as uncertainty arising from unobservable behavior of the transaction partner. Asset specificity refers to investments an actor makes exclusively for a transaction, and thus increases dependency on the other transaction actor (Rindfleisch and Heide, 1997). Increasing levels of uncertainty and asset specificity lead to higher transaction costs - which causes shifts from low control in market-type contract arrangements to higher control in hybrid - or hierarchy-type contract arrangements (Williamson, 2002). In this paper, we distinguish five types of contract arrangements (adapted from Wever et al., 2010 and van der Merwe et al., 2019): spot market exchange; non-contractual relationship; contractual relationship; equity-based contract; and vertical integration (VI) (Appendix Table A2).

The coordination of food quality in supply chains affects the choice for contract arrangements - for two reasons. First, final food quality is the result of decisions and behavior of all supply chain actors, which makes supply chain transactions interdependent (Trienekens et al., 2012). Second, food quality is multidimensional and consists of different quality attributes (Raynaud et al., 2005). Quality consists of search, experience and credence attributes (Darby and Karni, 1973). Search means that quality can be observed, such as size and appearance. Experience means that quality can be assessed during consumption, such as taste and texture. Credence means that quality cannot be observed or assessed, such as 
safety and process requirements. In this paper, we distinguish sensory, safety and process quality attributes (adapted from Luning and Marcelis, 2009). Sensory quality is a search or experience attribute, whereas safety and process are credence attributes.

Coordinating food quality in supply chains affects the transaction attributes of uncertainty and asset specificity (Young and Hobbs, 2002). The interdependence of behavior of supply chain actors to achieve the desired food quality and the unobservability of credence attributes lead to information asymmetries and uncertainty about the quality performance of partners. Transaction partners often invest in specific assets to comply with quality standards. Such investments increase bilateral dependency and create the risk of hold-up (Williamson, 1985). TCE predicts that if quality requirements go up, transaction costs go up (owing to higher uncertainty and asset specificity), which would lead to a shift from market-type to hierarchy-type contract arrangement (Ménard and Valceschini, 2005).

This paper follows the rationale that quality standards affect transaction characteristics, which in turn affect the choice of contract arrangement (Figure 1).

\subsection{Quality standards and contract arrangements}

Quality standards are an external coordinator of food quality in supply chains, and are considered to affect contract arrangements by changing the transaction characteristics. Through transmitting information on the product and production process, quality standards provide credible quality signals, which reduces buyers' search and measurement costs, particularly for credence attributes (Raynaud et al., 2009). However, implementing a quality standard leads to costs, such as for implementing good agricultural or manufacturing practices at production or processing nodes (Kirezieva et al., 2013). These investments are transaction specific if they only pay off the current partners. The effect of quality standards on uncertainty and asset specificity is, however, ambiguous. Empirical studies have found that public and private quality standards affect contract arrangements differently.

For public quality standards, Raynaud et al. (2005) find that the region-of-origin standard in three European agri-food supply chains leads to more market-type contract arrangements. Similarly, Fernández-Barcala et al. (2017) find that the same standard in European meat supply chains leads to more market-type contract arrangements. The authors show that the public quality standard adds layers of control to the supply chain, which allows contract arrangements to specialize in quality control, for instance, through monitoring and motivating compliance of the transaction partner. Public quality standards reduce uncertainty and lower the need for transaction partners to protect their reputational capital (Ménard and Valceschini, 2005). In addition, adherence to public standards is the responsibility of individual actors, therefore, not demanding additional coordination in more

Figure 1 Conceptual framework

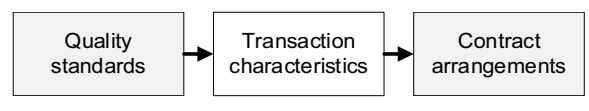

hierarchy-type contract arrangements (Trienekens and Wognum, 2013).

For private quality standards, Raynaud et al. (2005) find that private brand names lead to more hierarchy-type arrangements. These results are in line with Ghozzi et al. $(2016,2018)$ and Banterle and Stranieri (2008), who find that, respectively, nongenetically modified organism (GMO) standards in Europe and voluntary traceability standards in Italy lead to more hierarchy-type contract arrangements. Private quality standards reduce uncertainty, but increase asset specificity and therefore bilateral dependency - resulting in higher transaction costs, and thus more hierarchy-type contract arrangements. In conclusion, the effects of quality standards on contract arrangements seem to depend on their ability to influence the transaction characteristics. Especially, whether investments for a quality standard by transaction partners are truly transaction specific - which seems to be the case for private standards, contrary to public standards - affect levels of asset specificity and related levels of quality uncertainty that increase the risks of hold-up (Williamson, 1985; David and Han, 2004), and explains shifts to more market- or hierarchy-type contract arrangements (Ghozzi et al., 2018).

\section{Methods}

\subsection{Research context}

Dairy is the third largest agricultural export product of Uruguay, with an export value of US\$591m. Production is concentrated in the north and west of the country. In 2017, 3,718 dairy producers sent 1,822 million liters of raw milk to eight dairy processors (MGAP-DIEA, 2018). Processors process raw milk into a variety of dairy products, which are sold in three supply chains: domestic small retail, domestic supermarkets (33\% for the two supply chains combined) and export (67\%) (Inale, 2017). Butter and cheese are sold in all three supply chains, whereas perishable products like yoghurt and fresh milk are only sold in the domestic markets. Milk powder is the main export product, which is principally exported to Brazil, Algeria, Russia and Mexico (MGAPOpypa, 2018).

Citrus is the tenth largest agricultural export product of Uruguay, with an export value of US $\$ 80 \mathrm{~m}$. With a favorable production climate, citrus is predominantly produced in the north of the country. In 2017, 407 citrus producers sent 264,000 tons of citrus (50\% oranges, $35 \%$ mandarins and $15 \%$ lemons) to processors. The four largest producers account for $60 \%$ of all domestic citrus production, and are vertically integrated with processors. Processors clean citrus fruit and apply post-harvest treatments (MGAP-DIEA, 2018). Processors sell to three supply chains: domestic small retail, domestic supermarkets $(38 \%$ for the two supply chains combined) and export (40\%)[1]. Small- and medium-sized producers (below 20 hectares) predominantly supply domestic markets, whereas large producers supply all markets, including export. Main export markets are the USA and the EU, followed by Russia and Canada (MGAP-Opypa, 2018). Figure 2 shows that the dairy and citrus sectors are studied through analysis of bilateral transactions (T1-T4) that occur between several dyads in the supply chain. 
Figure 2 Three supply chains

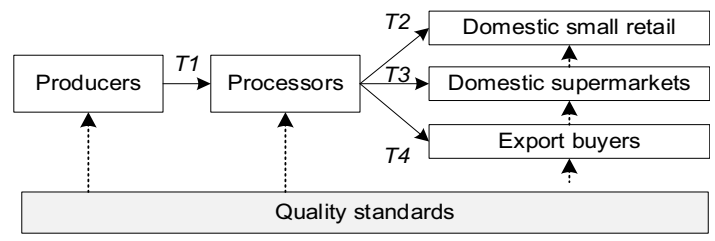

\subsection{Data collection and analysis}

A qualitative case-study design was applied, which is suitable for exploring causal links in complex real-life situations that need contextualized understandings (Yin, 2003). Two cases the dairy and citrus sectors in Uruguay - were selected, based on sector reports and explorative expert interviews. Selection criteria were the sectors' contribution to the agricultural GDP, perishability of produce and differences in production methods (animal versus fruit). A multiple embedded case study was applied, with two cases and multiple units within each case (Yin, 2003). Such a design has replication logic within and across cases, which is more rigorous and impactful than studies without replication logic (Hoorani et al., 2019).

Table 1 offers an overview of the primary and secondary data collection, which is further detailed in Appendix Table A1. The data were collected between November 2016 and April 2017. Twenty interviews were conducted for dairy, 19 for citrus. Selection of actors took place through an inventory of sector reports and websites. Processors were selected based on the condition that they sell in the export supply chain and in at least one domestic supply chain (small retail or supermarkets). In each sector, seven processors fulfilled that condition (MGAPOpypa, 2018). Four out of seven dairy processors participated, which provided a good representation of the dairy sector in terms of ownership types and milk volumes[2]. All seven citrus processors participated, although one was omitted because of incomplete data[3]. Processors and institutional actors were invited by email, with a formal letter attached explaining the purpose of the research, and guaranteeing confidential treatment of data. Interviews with processors were conducted with food quality and commercial managers. Interviews with institutional actors were conducted with experts on quality standards in the sector, as found in sector reports and through recommendations of other respondents. These interviews lasted between 50 and $80 \mathrm{~min}$. Subsequently, two to three supply chain actors per node were interviewed (Figure 2 and Appendix Table A1). Supply chain actors were sampled based on information from processors, and served to triangulate information on contract arrangements. These interviews lasted between 15 and $40 \mathrm{~min}$. All interviews were conducted in
Spanish by the principal researcher, recorded and subsequently transcribed.

To triangulate interview data, secondary data were collected. For public quality standards, a total of 60 national public decrees, regulations and laws that apply to dairy, citrus or both sectors were studied (Appendix Table A3). For private quality standards, a total of 15 private quality standards were studied that were implemented by a dairy or citrus processor, or both (Appendix Table A4). These private quality standards were obtained through websites and official standard documents, such as standard compliance criteria, quality requirements and audit documents. For contract arrangements, interview data from processors were complemented with secondary data from their website and annual reports. Additionally, secondary data on export requirements were analyzed. Based on processor respondents, secondary data of four export buyers for dairy (Nestlé, Unilever, FrieslandCampina and Danone) and four foreign retailers for citrus (Walmart, Kroger, Carrefour and Aldi) were analyzed.

Primary data were coded in Atlas.ti by the principal researcher. Coding was done deductively (using the topic list of the interviews) and inductively (based on new topics that arose from the data). For coding, quality attributes were distinguished for three attributes, and contract arrangements were distinguished for five types (Appendix Table A2 for coding rules on contract arrangements). Within-case and crosscase analyses were conducted - as advocated by Eisenhardt (1989) and Goertz and Mahoney (2012). The within-case analysis details descriptive write-ups for each case in Section 4, whereas the cross-case analysis is a comparative case search for patterns to aggregate findings, as used for analysis and discussions in Section 5.

\section{Results}

This section describes the results on quality standards and contract arrangements that are found in the supply chains of the dairy and citrus sectors in Uruguay.

\subsection{Dairy sector}

\subsubsection{Quality standards}

Table 2 details the quality requirements and control in public and private quality standards in the dairy supply chain.

Public quality standards have requirements on quality and control for all supply chain nodes.

For production, microbiological safety parameters are determined for raw milk, such as inhibitors of microbial growth, maximum residue levels (MRLs) [4] for fertilizers and veterinary medicines, and absence of prohibited products, such

Table 1 Data collection per topic

\begin{tabular}{lll}
\hline Topic & Primary interviews with & Secondary data on \\
\hline $\begin{array}{l}\text { Public QS } \\
\text { Private QS }\end{array}$ & Institutional actors & $\begin{array}{l}\text { National public decrees, laws and regulations } \\
\text { Processors: websites and annual reports }\end{array}$ \\
& Supply chain actor: processors & $\begin{array}{l}\text { For each private QS: websites, standard quality requirements and } \\
\text { audit documents } \\
\text { Contract arrangements }\end{array}$ \\
& $\begin{array}{l}\text { Supply chain actors: processors, producers, } \\
\text { small retail and supermarkets }\end{array}$ & $\begin{array}{l}\text { Export buyers: websites, documents on sourcing polices and quality } \\
\text { requirements }\end{array}$ \\
\hline
\end{tabular}


Annemarie Groot-Kormelinck, Facques Trienekens and Fos Bijman

Table 2 Quality standards in the dairy sector

\begin{tabular}{|c|c|c|}
\hline \multirow[b]{2}{*}{ Quality coordination } & \multicolumn{2}{|c|}{ Quality standards } \\
\hline & Public & Private \\
\hline Quality requirements & $\begin{array}{l}\text { - Animal welfare norms (production) } \\
\text { - Quality and safety parameters for raw milk and dairy } \\
\text { products (production and processing) } \\
\text { - Management of soil, water, effluents and agrochemical } \\
\text { residues (production and processing) } \\
\text { - Implementation of HACCP, traceability, auto-control } \\
\text { schemes and good manufacturing practices (processing) } \\
\text { - Safe and fair labor conditions (all nodes) } \\
\text { - Sanitary, hygiene and safety procedures for milk } \\
\text { production, collection, transport, processing, packaging, } \\
\text { storage and sales (all nodes) }\end{array}$ & $\begin{array}{l}\text { Seven ISO standards with guidelines for } \\
\text { management systems (processing): } \\
\text { - Food safety (HACCP and ISO 22000), food } \\
\text { quality (ISO 9001), generic food safety and } \\
\text { quality (FSSC 2000) and lab testing (ISO } \\
\text { 17025) } \\
\text { - Occupational health and safety (ISO 18001) } \\
\text { - Environmental (ISO 14001) and energy } \\
\text { management (ISO 50001) }\end{array}$ \\
\hline Quality control & $\begin{array}{l}\text { - Accreditation and sanitary export certificates (processing) } \\
\text { - Lab control of cow urine, raw milk and dairy products } \\
\text { (production and processing) } \\
\text { - Accreditation and periodic control (all nodes) }\end{array}$ & $\begin{array}{l}\text { Certification and annual audits by third-party } \\
\text { certification bodies }\end{array}$ \\
\hline
\end{tabular}

as growth hormones and antibiotics (decree 174/002). Hygienic and safety procedures are prescribed to ensure health of personnel (laws 13.130, 13.389, 14.785 and decree 321/ 009), animal welfare (laws 18.471 and 18.242), sanity of cows and hygienic milking and storing (decree 315/994, Mgap, 2018). Producers need to register and obtain annual accreditation, and are controlled and sanctioned by the Ministry of Livestock, Agriculture and Fisheries (hereafter Ministry of Agriculture) on sanitation of cows and raw milk through lab analysis (decree 174/002).

For processing, physical and chemical quality and safety parameters of raw milk are determined[5]. These parameters are set to equal norms of the European Union (EU) (the destination market with the highest demands) to enable processors to export to all markets (decrees 315/994, $359 / 013$ and 382/016). Traceability is required, and detailed procedures prescribe milk processing per dairy product (decree 174/002). General requirements for food industries (valid for dairy and citrus) involve food safety prescriptions for processing, packaging, labelling, storage and transport (decree 315/994), and safety and health of personnel in the working environment (decrees 291/007 and 127/014). Additionally, general requirements are set for safe and fair labor conditions, such as working hours, payment, insurances and conflict resolution (laws 18.441 and 14.407), and for environmental norms, such as management of soil, water, effluents and agrochemical residues (decrees 182/013, 152/013 and 253/79).

Processors are required to make several investments, such as the implementation of Hazard Analysis and Critical Control Points (HACCP), traceability, auto-control schemes and a manual on good manufacturing practices that details internal control of products, operations, procedures for cleaning, health and hygiene of staff and programs for staff capacitation, water quality and pest control. Processors need to implement a traceability system, control accreditation, communicate lists of supplying producers and communicate producers that violate public quality norms to the Ministry of Agriculture (law 18.242 and decree 174/002). They are also required to conduct lab analysis of raw milk and dairy products - of which the frequency, number of samples, parameters, control techniques and sanctions are publicly defined (decree 382/016). Processors need to register and obtain annual accreditation, including sanitary certificates for each export market. Processors are controlled by several ministries, and additional public lab control is conducted on raw milk and dairy products (decrees 368/2000, 65/2003, 359/013 and 62/2002), as well as on safe labor practices and work authorizations (laws 14.489 and 15.903).

For retailing, general basic safety and hygienic requirements exist (valid for dairy and citrus), such as for loading and unloading products. The public requirements for domestic supermarkets (T3) are more extensive than for domestic small retail (T2), for example, with additional rules for refrigeration, separate offloading areas and staff hygiene (decree 174/002). All nodes of the chain are subject to annual or more frequent controls and inspections. Appendix Table A3 provides more details on the public standards in the dairy sector.

Private quality standards have requirements for quality procedures for the processing node only. A total of seven ISO standards and HACCP, with varying adoption rates, are implemented by processors. HACCP (100\% adoption) has a technical focus, and sets guidelines for hazard analysis, determining critical control points and critical limits, and implementing procedures for monitoring, corrective actions, verification and record-keeping. The ISO standards have a management focus, and prescribe frameworks and guidelines to improve procedures at company level. The adopted standards focus on system improvements on food safety management (ISO 22000, 100\% adoption), quality management (ISO 9001, 75\% adoption), food safety and quality management (FSSC 22000,[6] 50\% adoption), occupational health and safety (ISO, 18001, 25\% adoption), environmental management (ISO 14001, 50\% adoption), energy management (ISO 50001, 50\% adoption) and lab 
testing (ISO 17025, 25\% adoption). Contrary to public standards, these ISO standards are less specific for the investments that processors should make for successful standard implementation. Depending on the focus of the standard, processors may invest in design of preventive measures (e.g. design of sanitation program), assurance activities (e.g. record keeping), and implementing monitoring and control activities (e.g. design of corrective actions) - in addition to certification and auditing costs. Compliance with ISO standards is annually controlled by third-party auditors. Appendix Table A4 provides more details on the private standards in the dairy sector.

\subsubsection{Contract arrangements}

Table 3 presents the type of contract arrangements and the corresponding quality requirements and control for different dyads in the dairy supply chain. Averages are given for the type of contract arrangement among all processors under study, although variations are described.

Contract arrangements between producers and processors (T1) are contractual relationships and equity-based contracts. One processor has a contractual relationship with its suppliers, another processor has a contractual relationship and equitybased contract, [7] whereas a third processor is an equity-based cooperative, and a fourth is vertically integrated. Although the contracts have a one-year duration, they get repeated over numerous years. Many producers supply to the same dairy company for their entire work life. The processor with the contractual relationship equals milk safety parameters to the public quality standard, whereas - in anticipation to most demanding export buyers - the other three processors set stricter parameters [8]. Processors exert strict quality control on raw milk, by conducting rapid analysis in milk tanks (e.g. on antibiotics), and elaborate lab analyses on microbiological, physical and chemical quality and safety parameters [9].
Analysis results are used by all processors with producer suppliers (excluding the vertically integrated processor) for a quality-based payment system that rewards better sensory quality and safety, and punishes antibiotics [10]. Two of the three processors with producer suppliers have in-house veterinarians and agronomists that inspect the sanitary situations on the farm. To a varying degree, processors additionally stimulate quality by providing production inputs, credit and pre-financing private veterinarian and agronomic assistance to producers, and by stimulating quality improvements through projects and workshops - often with public support.

Contract arrangements between processors and domestic small retail (T2) are non-contractual and contractual relationships with intermediary distributors. Distributors are responsible for the sales-based coordination and distribution with networks of small shops. Contract arrangements between dairy processors and domestic supermarkets (T3) are annually recurring contractual relationships. For both contract arrangements in $\mathrm{T} 2$ and $\mathrm{T} 3$, no quality requirements or control takes place, given that processors do not manufacture dairy products based on direct quality requirements from small retail and domestic supermarkets. For small retail (T2), agreements are based on price margins and logistics, whereas supermarket contracts (T3) specify the number and shelf-space per dairy product, and stipulate price, payment and discount systems.

Contract arrangements between processors and export buyers (T4) are contractual relationships. Export buyers are multinational dairy and food manufacturing companies that buy dairy products to sell or transform into other products. Most buyers require milk safety and quality parameters equal to the public quality standard (these parameters equal those of the EU, the most demanding market), and have additional

Table 3 Contract arrangements in the dairy sector

\begin{tabular}{|c|c|c|c|c|}
\hline $\begin{array}{l}\text { Quality } \\
\text { coordination }\end{array}$ & Producers - processors (T1) & $\begin{array}{l}\text { Processors - Small retail } \\
\text { (T2) }\end{array}$ & $\begin{array}{l}\text { Processors - supermarkets } \\
\text { (T3) }\end{array}$ & Processors - export buyers (T4) \\
\hline CA type & $\begin{array}{l}\text { Mix of contractual relationship } \\
\text { and equity-based contract }\end{array}$ & $\begin{array}{l}\text { Mix of (non)-contractual and } \\
\text { contractual relationship }\end{array}$ & Contractual relationship & Contractual relationship \\
\hline $\begin{array}{l}\text { Quality } \\
\text { requirements }\end{array}$ & $\begin{array}{l}\text { - Internal coordination of } \\
\text { requirements from public } \\
\text { and private QS and export } \\
\text { buyers }\end{array}$ & $--^{a}$ & -- & $\begin{array}{l}\text { - Milk quality and safety } \\
\text { parameters } \\
\text { - Packaging/labelling information } \\
\text { - Traceability systems } \\
\text { Some buyers: } \\
\text { - Private quality standards } \\
\text { (e.g. FSSC } 22000 \text { and ISO 9001) } \\
\text { - Safety procedures and process } \\
\text { requirements (social, animal } \\
\text { welfare and environmental) }\end{array}$ \\
\hline Quality control & $\begin{array}{l}\text { - Lab control on raw milk } \\
\text { - Farm inspections on cows } \\
\text { and milk sanitation }\end{array}$ & -- & -- & $\begin{array}{l}\text { - Lab control on dairy products } \\
\text { Some buyers: } \\
\text { - Coordinating missions } \\
\text { - Audits (private or third party) }\end{array}$ \\
\hline
\end{tabular}

Note: ${ }^{\mathrm{a}}$ For contract arrangements in $\mathrm{T} 2$ and $\mathrm{T} 3$, no quality requirements or control takes place, given that processes do not manufacture dairy products based on direct quality requirements of small retail and supermarkets 
requirements on packaging, labelling and traceability systems. The most demanding export buyers (multinational dairy companies) insist on milk safety and quality parameters stricter than the public standard (see endnote 8), and require processors to adopt one or multiple private quality standards, with requirements for the processing node only.

Going beyond public and private standards, the most demanding export buyers (T4) set additional quality requirements for safety procedures and process quality on social practices, animal welfare and environmental management. These requirements are implemented through buyer-owned quality guidelines and manuals, online monitoring systems and codes of conduct. Before the first transaction, these export buyers often visit dairy processors (or vice versa) to coordinate quality requirements. Subsequent transactions are sales-based purchase orders that focus on volume, price, logistics and technical quality specifications of milk products. Transactions are often repeated (monthly to six months) and only a minor part is sold on the spot - in response to fluctuating global market demand. Quality control takes place through elaborate lab control on quality, safety and sensory parameters. In addition, the most demanding export buyers send third-party auditors to inspect producers and processors with regard to these private requirements.

\subsection{Citrus sector}

\subsubsection{Quality standards}

Table 4 details the quality requirements and control in public and private quality standards in the citrus supply chain.

Public quality standards for the production node entail safety, social and environmental requirements.

For production, safety parameters for MRL of agrochemicals are those of the Codex Alimentarius, which are substantially less strict than the most demanding export market, the EU. Various norms prescribe safety procedures to ensure safe purchase, storage and disposition of agrochemicals (law 13.663). Other requirements prescribe safe and hygienic onsite handling to reduce incidence of sanitary diseases (decree 535/003 and law 16.332). Producers need accreditation from the Ministry of Agriculture, and of the national authority of environment. Strict on-site public quality control takes place on sanitary diseases.

For processing, similar safety parameters on MRL for agrochemicals apply. A range of generic industry requirements (that also apply to dairy processors) specify safety and hygienic procedures for processing, transport, packaging, labelling and storage (decree 315/994), for safety and health of personnel (decree 291/007), labor conditions (law 18.441) and environmental management of soil, water and residues (decree 182/013). Processors need accreditation and are controlled by several ministries, for instance, on safety and environmental requirements. Processors are subjected to strict control on sanitary diseases, upon which accreditation for the highest demanding export markets is contingent. Processor respondents, for example, indicate the presence of a permanent public officer in their packing plant to continuously monitor the sanitary situation.

For retailing, the same generic requirements (that also apply to dairy) exist for basic safety and hygienic requirements for domestic small retail (T2) and domestic supermarkets (T3) (decree 174/002). Samples of citrus fruit are taken at production, processor, wholesale and retail nodes for lab analysis on MRL - although respondents reported low implementation, among other challenges [11]. Finally, all actors in the chain are subject to annual and more frequent controls and inspections. Appendix Table A3 provides more details on the public standards in the citrus sector.

Private quality standards set requirements for safety procedures, social and environmental norms. A total of nine standards are implemented by processors. Five of these standards have requirements for production and processing nodes. GlobalGap (100\% adoption) is a broad standard with food safety, social and environmental requirements through good agricultural practices - with requirements ranging from pre-harvest activities to post-harvest handling. Record keeping and internal audits are required on, among others, food safety assessments, hygiene protocols, traceability, working conditions, pest management and conservation of water, soil

Table 4 Quality standards in the citrus sector

\begin{tabular}{lll}
\hline Quality coordination & Public & \multicolumn{2}{c}{ Quality standards } \\
Quality requirements & - MRL for agrochemicals (production and processing) & Nine standards with requirements for production and/or \\
- Sustainable soil, energy and water management & processing nodes: \\
& (production and processing) & - Broad food safety, social and environmental norms \\
- Safe and fair labor conditions (all nodes) & (GlobalGap, Tesco Nurture) \\
- Sanitary, hygiene and safety procedures for production, & - Food safety (HACCP, BRC and OHSAS 1800), quality \\
& harvesting, processing, packaging, transport, storage & (ISO 9001), generic food safety and quality (FSSC \\
& and sales (all nodes) & 22000) \\
& - Accreditation and sanitary export certificates & - Social/ethical norms (GRASP and SMETA) \\
Quality control & (processing) & certification and annual audits by third-party \\
& - Sanitary disease control (production and processing) & \\
- Basic lab control on MRL (all nodes) & \\
- Accreditation and periodic control (all nodes) &
\end{tabular}

Note: $M R L=$ Maximum residue levels 
and biodiversity. Tesco Nurture (50\% adoption) is the only single-retailer standard of the nine, and to avoid duplication for processors, has merged the majority of its social and environmental requirements with GlobalGap. Tesco's safety procedures on agrochemical applications, however, are more stringent than GlobalGap, for example, with obligatory lab analysis to be conducted by processors, and stricter requirements on agrochemical application records.

GlobalGap Risk Assessment on Social Practices in agricultural operations (GRASP, 50\% adoption) is a social add-on to GlobalGap, and sets requirements for fair social practices, such as employee representation, complaint procedures and documentation of contracts, wages and non-employment of minors. Sedex Members Ethical Trade Audit (SMETA, 50\% adoption) is another social standard that sets requirements for ethical business practices, with requirements for a management system on freedom of association and employment, health and safety, child labor, labor conditions and discrimination, among others. The Food Safety System Certification (FSSC 22000, 17\% adoption) sets guidelines for a generic food safety and quality management system. The following four quality standards set requirements for the processing node only. HACCP (100\% adoption) sets guidelines for hazard analysis and control. British Retail Consortium (BRC, 67\% adoption) sets requirements for food safety, such as the implementation of HACCP and management systems for safety, quality, packaging, traceability, hygienic product and process control, side standards and staff training. Finally, ISO 9001 (34\% adoption) and Occupational Health and Safety Assessment Series (OHSAS 18000, 17\% adoption) require implementation of management systems on food quality and occupational health and safety, respectively. All the above standards are audited annually by third-party auditors. Appendix Table A4 provides more details on the private standards in the citrus sector.

\subsubsection{Contract arrangements}

Table 5 presents the type of contract arrangements and the corresponding quality requirements and control for different dyads in the citrus supply chain.

The contract arrangement between production and processing (T1) is VI. Five of the six processors have production and processing vertically integrated. The sixth processor is an equity-based cooperative in which producers manage their own production, whereas the processor decides on timing and volumes of harvesting. The three processors with the largest production volumes have commercialization integrated vertically as well, whereas the three smallest processors (two VI and the equity-based cooperative) have a shared strategic alliance with an agency that commercializes their produce for export. All six processors have a high level of internal coordination to assure compliance with quality requirements from the public and private quality standards and from contract arrangements downstream the chain. For three processors, the export agency adds quality requirements and control. The six processors have continuous alignment of production, harvesting and packaging processes, implementing quality standard requirements and controlling compliance thereof - for example, through sanitary management protocols and internal lab analysis on agrochemicals.

Contract arrangements between processors and domestic small retail (T2) are spot market exchanges and non-contractual relationships. Transactions take place in the national wholesale market, whereby processors have their own stand or sell through other operators. Although most buyers may have a preference for larger-sized fruit with a clean skin, these preferences are not coordinated as quality requirements ex ante to the transaction, nor is there quality control. Buyers come to the wholesale market, search for fruit that has their preferred cosmetic quality and price, negotiate and pay.

Table 5 Contract arrangements in the citrus sector

\begin{tabular}{|c|c|c|c|c|}
\hline $\begin{array}{l}\text { Quality } \\
\text { coordination }\end{array}$ & Producers - processors (T1) & $\begin{array}{l}\text { Processors - small retail } \\
\text { (T2) }\end{array}$ & $\begin{array}{l}\text { Processors - supermarkets } \\
\text { (T3) }\end{array}$ & Processors - export buyers (T4) \\
\hline CA type & Vertical integration & $\begin{array}{l}\text { Mix of spot market - non- } \\
\text { contractual relationship }\end{array}$ & Contractual relationship & Contractual relationship \\
\hline $\begin{array}{l}\text { Quality } \\
\text { requirements }\end{array}$ & $\begin{array}{l}\text { - Internal coordination of } \\
\text { export buyer requirements } \\
\text { and public and private QS }\end{array}$ & - Size and cleanliness of skin & $\begin{array}{l}\text { - Size, caliber and cleanliness } \\
\text { of skin } \\
\text { - Consistent quality } \\
\text { - Packaging } \\
\text { - Informal traceability }\end{array}$ & $\begin{array}{l}\text { - Size, caliber and cleanliness of skin } \\
\text { - Internal quality (e.g. sugar levels and } \\
\text { texture) } \\
\text { - Consistent quality } \\
\text { - Packaging and labelling } \\
\text { - Traceability systems } \\
\text { Some buyers: } \\
\text { - Stricter on number, types and MRL of } \\
\text { agrochemicals } \\
\text { - Private quality standards } \\
\text { - Codes of conduct }\end{array}$ \\
\hline \multirow[t]{2}{*}{ Quality control } & $\begin{array}{l}\text { - Visual inspection } \\
\text { - Lab control on MRL }\end{array}$ & -- & $\begin{array}{l}\text { - Visual inspection } \\
\text { - Lab control on MRL } \\
\text { - Annual coordination visits }\end{array}$ & $\begin{array}{l}\text { - Visual inspection } \\
\text { - Advanced lab control on MRL }\end{array}$ \\
\hline & & & & $\begin{array}{l}\text { Some buyers: } \\
\text { - Annual coordination visits } \\
\text { - Audits (private or third party) }\end{array}$ \\
\hline
\end{tabular}

Note: $M R L=$ Maximum residue levels 
Contract arrangements between processors and domestic supermarkets (T3) are annually repeated contractual relationships with two of the six processors. Because these supermarkets already have a preferred supplier relation with a single processor, the other four processors do not supply to domestic supermarkets. Sensory quality requirements are coordinated, such as size and cleanliness of skin (class 1 or 2) - which are stricter than the preferences of buyers in small retail (T2). Supermarkets set additional requirements for consistent quality, uniform packaging and informal traceability (knowing the producers of a batch, but not using a formal barcode system). Although daily coordination of volume and price for next day deliveries are communicated through purchase orders, quality and non-quality requirements, such as pricing and payment systems, promotions and logistics, are coordinated through annual contracts. Additionally, supermarkets pay annual visits to producers. Quality control is carried out by visual inspection. Two of the three supermarkets conduct basic lab control, and sanction producers with a fine or temporary suspension when MRL exceeds the public standard norms.

Contract arrangements between processors and export buyers (T4) are contractual relationships. Export buyers are large retailers that often buy through importers, such as fruit wholesalers. Buyers set detailed requirements on sensory quality, such as size, cleanliness of skin (class 1 or 2), sugar levels and texture - which are stricter and more elaborate than the requirements of domestic supermarkets. Buyers set additional requirements for consistent quality, packaging and labelling, traceability systems and transport. Buyers also demand adoption of private quality standards. GlobalGap is demanded by all buyers, thus, obligatory de facto for export market access, whereas additional standards may be demanded, such as BRC, GRASP or Tesco Nurture. Some of the most demanding European retailers set stricter product safety requirements, for example, allowing fewer agrochemical products and demanding 70\% MRL of EU norms.

Going beyond public and private standards, large retailers in T4 have suppliers sign their private code of conduct on food safety and process quality. Retailers often provide training and support for suppliers to comply with their private quality requirements. Before the first transaction, processors regularly visit new buyers to coordinate requirements. Processors also have annual planning meetings with clients at a global fruit fair in Berlin. Given that both quality and non-quality requirements (e.g. on payment system and logistics) are established in the contract, subsequent transactions occur through sales-based purchase orders that specify volume, price and desired quality per variety of citrus. The majority of agreements is with repeated clients, only a minor part is sold on the spot. Processors inform buyers on actual MRL for all their varieties. Intermediary importers control compliance, after which buyers also conduct sanitary and organoleptic analyses, in addition to visual inspections on size and cosmetic quality, maturity and sugar levels. Large retailers send third-party auditors or intermediaries to verify compliance with their private requirements.

\section{Analysis and discussion}

This section presents the results of the cross-case analysis, which lead to two main findings. Figure 3 shows specific combinations of quality standards and contract arrangements for each transaction. Figure 4 provides insights in whether quality standards function as substitutes for or as complements to contract arrangements. The figure shows specific combinations of quality standards and contract arrangements to coordinate quality attributes for each transaction.

\subsection{Finding 1: upstream vs downstream}

The first finding is that the influence of quality standards on contract arrangements differs according to the place of transactions within supply chains. We find quality standards to complement contract arrangements in upstream transactions (T1). Contract arrangements set additional quality requirements and control in hierarchy-type contract arrangements. On the contrary, we find quality standards to substitute contract arrangements in downstream transactions (T2, T3 and T4). Contract arrangements set few additional requirements and control in market-or hybrid-type contract arrangements.

In upstream transactions between producers and processors (T1), the combination of public and private standards complement contract arrangements on all quality attributes. To complement quality standards, contract arrangements set additional requirements of sensory, safety and process quality requirements (Figure 4). Hierarchy-type contract arrangements include strong quality incentives and controls to assure producers' compliance with the quality standards and the additional requirements agreed in the contract arrangement.

Figure 3 How transactions make use of quality standards and contract arrangement types

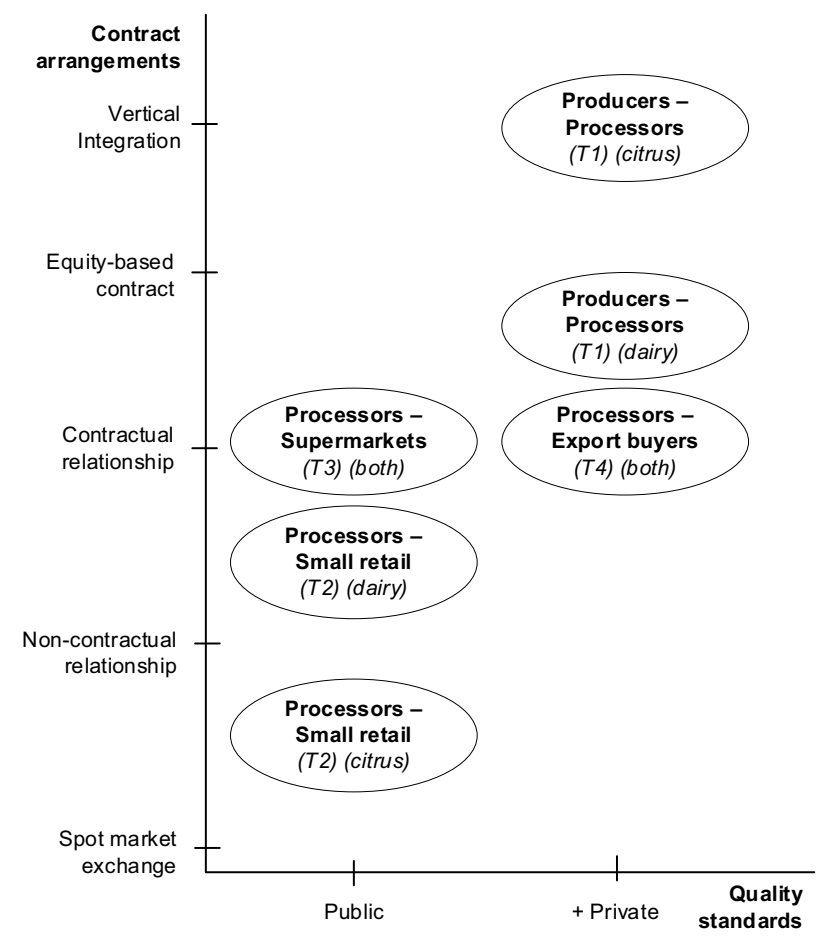


Annemarie Groot-Kormelinck, Facques Trienekens and fos Bijman

Figure 4 Combinations of quality standards and contract arrangements for different quality attributes in transactions

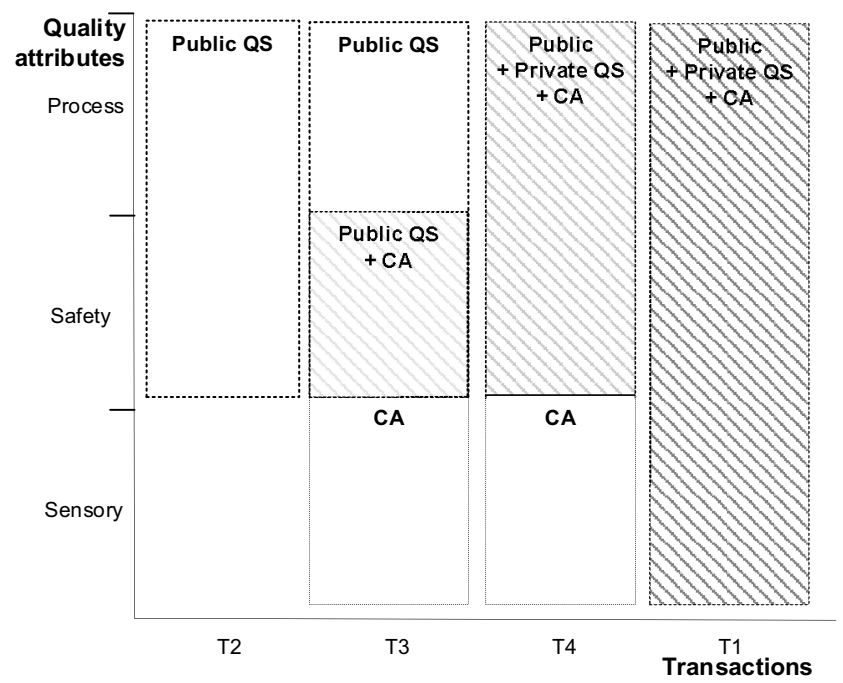

Notes: Public QS $=$ Qs substitutes CA, in obtaining quality coordination; Diagonal shading $=\mathrm{QS}$ complements $\mathrm{CA}$, in obtaining quality coordination; From T2 to T3 to T4: substitution effects of QS decrease (diagonal shading increases to multiple quality attributes); T1: QS complements CA for all quality attributes

These contract arrangements are designed for the most demanding buyers (export buyers, T4). Contract arrangements in citrus are VI with hierarchical control, whereas contract arrangements in dairy are equity-based contracts with quality incentives in pricing mechanisms and service delivery (Figure 3). As a citrus processor stated "We get audits from public and private standards, including from private export buyers. We are always running backwards with production to get everything perfect, with hundred per cent quality".

This finding for upstream transactions is in line with findings on private brand names (Raynaud et al., 2005), non-GMO standards (Ghozzi et al., 2016, 2018) and voluntary traceability standards (Banterle and Stranieri, 2008), which all lead to more hierarchy-type contract arrangements. In line with TCE predictions, we found that quality standards increase specific investments and quality uncertainty for upstream transactions. In our cases, the majority of quality requirements is implemented at the production and processing nodes, for which producers and processors make significant, interdependent investments. For example, public quality standards in dairy oblige processors to test producers' raw milk quality, and private quality standards in citrus oblige processors to document producers' use of agrochemical products. Thus, processors depend on the quality performance of producers for their own quality assurance. Quality standards insufficiently reduce quality uncertainty for processors, owing to measurement difficulties of credence attributes, unobservability of the transaction partners' behavior and given that periodic controls of quality standards seem insufficient for processors to guarantee compliance. Subsequently, transaction costs increase and more contractual safeguards are needed - which makes a hierarchy-type of contract arrangement appropriate.

In downstream transactions between processors and buyers in three supply chains (T2, T3 and T4), quality standards substitute contract arrangements on credence requirements of safety and process quality (Figure 4). Quality standards are combined with market- or hybrid-type contract arrangements. Our finding is in line with findings of Raynaud et al. (2005) and Fernández-Barcala et al. (2017), who find region-of-origin standards in different European supply chains to lead to more market-type contract arrangements. As TCE predicts, quality standards reduce buyers' quality uncertainty and reduce asset specificity and dependency between processors and buyers. In our cases, buyers in downstream transactions are retailers, who demand adoption of private quality standards in addition to requirements in the contract arrangement. Given that most quality standards are implemented at production and processing nodes, quality standards transfer monitoring and control to the upstream transaction. Subsequently, transaction costs decrease and fewer contractual safeguards are needed which makes a market- or hybrid-type of contract arrangement appropriate.

Our findings lead to the following propositions:

P1. Quality standards complement contract arrangements for upstream transactions, because quality standards alone insufficiently reduce uncertainty and risks from specific investments.

P2. Quality standards (partially) substitute contract arrangements for downstream transactions, because quality standards sufficiently reduce uncertainty and risks from specific investments.

\subsection{Finding 2: downstream differences}

The second finding is that the substitution effect of quality standards on contract arrangements differs for downstream transactions across different supply chains. This finding builds further on the first finding, by showing that the substitution effect is strongest for contract arrangements between processors and domestic small retail buyers (T2), followed by domestic supermarkets (T3) and export buyers (T4). Figure 4 shows that public quality standards substitute contract arrangements for $\mathrm{T} 2$. The substitution effect gradually decreases in T3 where the coordination of safety attributes in quality standards is complemented with contract arrangements. The figure shows that the substitution effect further decreases in T4, where safety and process quality attributes in quality standards are complemented with contract arrangements.

In T2 transactions between processors and domestic small retail, public standards substitute contract arrangements on safety and process requirements and control. These contract arrangements are market-type contract arrangements without additional contractual requirements on sensory, safety or process quality. As a citrus wholesaler states:

We have buyers for all kinds of visual quality, but we never discuss quality beforehand with our producers or buyers. [...] Government representatives take samples for residue analysis, but buyers never ask me about residue outcomes, or how ethical or sustainable the fruit is produced. 
In T3 transactions between processors and domestic supermarkets, public standards substitute contract arrangements on safety procedures and process quality for dairy, but not entirely for citrus. Contract arrangements are a hybrid-type of arrangement, whereby for citrus, contract arrangements set additional control on safety that is not covered by the public quality standard, such as pesticide residue analysis. As this supermarket manager states:

We started to do our own pesticide analysis, because we noticed an increased consumer concern on agrochemical residues found in Uruguay, and we consider public control not sufficient for us.

In addition, these citrus contract arrangements set basic guidelines on sensory quality.

In T4 transactions between processors and export buyers, public and private standards partially substitute contract arrangements on safety and process quality. The adoption of private quality standards by processors is demanded by export buyers. Contract arrangements are a hybrid-type of arrangement, whereby only the most demanding dairy and citrus export buyers set more stringent product safety requirements, such as lower bacterial milk values or lower agrochemical residue levels. Moreover, these most demanding export buyers set additional requirements on process quality, such as private codes of conduct on social and sustainable practices, to which compliance is audited privately, often by third parties [12]. Processors indicate that external audits for private standards reduce needs for requirement setting and control in the contract arrangement:

Private standards help to open more strategic markets. Buyers do not need to set similar quality requirements, or send their own auditors, because the certification shows our quality management procedures are in place.

To our knowledge, this is the first study on quality standards and contract arrangements that not only compares transactions within supply chains, but also analyzes effects across downstream transactions in three supply chains. Based on TCE reasoning and in line with Young and Hobbs (2002), we argue that a gradual increase in the complexity of credence requirements (from $\mathrm{T} 2$ to $\mathrm{T} 3$ to $\mathrm{T} 4$ ) explains the different substitution effects of quality standards on contract arrangements for the three downstream transactions. First, contract arrangements are market-type when public quality standards substitute credence attributes in contract arrangements. For these transactions (T2), contract arrangements do not set additional requirements (dairy), or they only set requirements for search attributes, such as visual quality (citrus). Second, contract arrangements shift to a hybrid type when public quality standards substitute most credence attributes in contract arrangements. For these transactions (T3), buyers require additional control in the contract arrangement, such as analyses on pesticide residues. Third, whereas private quality standards, as demanded by export buyers, substitute to a large extent the requirements for credence attributes in contract arrangements, the most demanding export buyers set additional requirements and control for credence attributes. These additional requirements explain a further increase in control in the hybrid-type contract arrangements (as compared to T3) (Figures 3 and 4). Thus, increases in requirements for unobservable credence attributes, such as safety and process quality, increase information asymmetry and therefore quality uncertainty for buyers. This results in higher transaction costs and higher needs for contractual safeguards, explaining the shifts from the marketto the hybrid-type contract arrangements.

Our findings lead to the following proposition:

P3. Quality standards affect contract arrangements differently across supply chains, depending on the complexity of credence requirements by downstream buyers, influencing uncertainty and risks from specific investments.

\section{Conclusions and implications}

The increased importance of coordinating food quality in supply chains has resulted in studies on the relation between quality standards and supply chain governance. This paper investigated the influence of quality standards on bilateral contract arrangements in different stages of food supply chains. A qualitative double case study was conducted on the dairy and citrus sectors of Uruguay. For each sector, public and private quality standards and contract arrangements were studied for transactions that processors - the focal supply chain company have with upstream producers and with downstream buyers in three supply chains. Within-case and cross-case analyses were conducted to understand whether quality standards substitute or complement contract arrangements, through comparisons on specific quality attributes.

\subsection{Policy and managerial implications}

Our findings have several policy and managerial implications. Supply chain actors can reduce transaction costs and improve efficiency of operations and transactions when they seek optimal alignment between quality standards and contract arrangements. Given the interdependency of transactions, actors that are intermediary between upstream and downstream transactions need to design contract arrangements that take the full chain into account. Processors can improve supply chain coordination by better communicating their quality requirements and implementing a combination of formal and informal quality monitoring mechanisms. Governments can support supply chain coordination for food quality, for instance, by facilitating the establishment of chainwide quality monitoring and control organizations. In our case, the government established a national public-private organization that supports quality performance of the entire dairy chain. In addition, public support can facilitate access to the most demanding export markets by providing sanitary export certificates, foreign trade missions and aligning public quality standards with export market requirements.

\subsection{Limitations and directions for future research}

Our paper is not without limitations. First, detailed comparisons between the dairy and citrus sectors were excluded. Although we found similar results for both sectors, we recommend future research to explore wider product, market and institutional characteristics that may explain differences across agricultural sectors. Second, analysis of plural contract arrangements, such as dairy processors having both vertically integrated milk production and contracts with independent producers, was beyond the scope of this paper. 
Such plural governance forms provide interesting opportunities for future research, in line with research by Menard (2013) and Mugwagwa et al. (2019). Third, we acknowledge the limited number of interviews per supply chain actor, and the crosssectional research design, which only allowed measurement of quality standards and contract arrangements at one point in time. Longitudinal studies that analyze changes in contract arrangements over time would be an interesting area for future research.

\subsection{Contributions and concluding remarks}

Our findings show that quality standards affect contract arrangements differently depending on the place of transactions within supply chains. In the upstream part of the supply chain, quality standards complement contract arrangements. These contract arrangements are of a hierarchy-type that sets additional sensory, safety and process quality requirements, and provides additional quality incentives and control (P1). In the downstream part of the supply chain, quality standards substitute contract arrangements (P2). The substitution effect in downstream transactions is strongest for contract arrangements between processors and domestic small retail, followed by domestic supermarkets and export buyers. These contract arrangements are of a market- or hybrid-type that sets limited additional quality requirements and control (P3). Quality standards increase specific investments and quality uncertainty for upstream transactions, but decrease these transaction characteristics for downstream transactions. Moreover, the substitution effect decreases when the complexity of credence requirements in upstream transactions increases.

This paper provides several contributions to the existing literature on quality standards and contract arrangements in supply chains. First, we contribute to the debate on whether quality standards and contract arrangements are complements or substitutes in food quality coordination (Goodhue, 2011), by showing that they can be both, depending on the place of the transaction within the supply chain - upstream or downstream. Our findings go beyond studies that investigate dyadic transactions (Raynaud et al., 2005; Banterle and Stranieri, 2008), or studies that find quality standards to affect all supply chain transactions similarly (Fernández-Barcala et al., 2017).

Second, this paper shows that supply chain transactions are interdependent on one another within the coordination of food quality. The adoption of private quality standards, as required by retailers in downstream transactions, has implications for the requirements in upstream transactions. Upstream transactions are designed to comply with the most demanding buyers, in our case export buyers. This implies that requirements for quality standards in downstream transactions affect the design of contract arrangements in upstream transactions. Our study answers the call in supply chain management literature to address interdependencies and spillover effects across multiple transactions (Mena et al., 2013; Kataike et al., 2019). Our two final contributions add insight into the application of TCE in supply chain management.

Third, we use TCE to discuss how quality standards affect contract arrangements by changing the transaction characteristics. We do this through detailed empirical comparisons on quality attributes in quality standards vs contract arrangements. This advances studies of Wever et al. (2010) and Trienekens and Wognum (2013), who relate quality standards to contract arrangements without explaining how such effects come about.

Finally, to the best of our knowledge, this is the first study that explores the combination of public and private quality standards. Studies on single-quality standards agree that quality standards reduce uncertainty, but find private standards to increase asset specificity (Banterle and Stranieri, 2008; Ghozzi et al., 2016), and public standards to reduce asset specificity (Raynaud et al., 2005; Fernández-Barcala et al., 2017) - resulting in ambiguous effects on contract arrangements. We found that public and private quality standards show a significant overlap in their quality requirements; high adoption rates of private standards reduce asset specific investments; and requirements of different private quality standards are increasingly harmonized to reduce duplication efforts - which is also stated by Henson and Humphrey (2010). Thus, we conclude that the simultaneous adoption of multiple public and private standards makes investments in private standards less specific. Effects of quality standards on contract arrangements seem therefore to be not so much explained by asset specificity, but more by uncertainty which is also stated by Ménard and Valceschini (2005). We recommend future studies to refrain from focusing on a singlequality standard in isolation, but to include all quality standards and thus further improve our understanding of the complexity of quality coordination in food supply chains.

\section{Notes}

1 Twenty-one percent of fruit is sold to juice processors, $2 \%$ are post-harvest losses.

2 Processor 1: a family company with 45 producers (2\%); Processor 2: a cooperative with 20 member and 60 nonmember producers (3\%); Processor 3: an investor-owned firm with vertical integration (own milk production) (5\%); Processor 4: a cooperative with 1,800 producers (71\%). Percentages are litres of milk processed/all milk processed in Uruguay in 2017 (MGAP-Opypa, 2018).

3 Processor 1: a family company (2\%); Processor 2: a listed company (4\%); Processor 3: a cooperative (6\%); Processor 4: a family company (6\%); Processor 5: an international listed company (11\%); Processor 6: a listed company (14\%). Given the lack of data on citrus volumes processed in Uruguay, the percentages represent export market value/total citrus export market value in Uruguay in 2017 (MGAP-Opypa, 2018).

4 See Appendix Table A5 for a list of abbreviations and acronyms.

5 Sensory: minimum fat: $2.9 \mathrm{~g} / \mathrm{cc}$, protein: $2.7 \mathrm{~g} / \mathrm{cc}$. Safety: $<400,000$ white blood cells/mL for somatic cell count and $<100,000$ bacterial cells/mL for bacterial count (decree 382/ 016).

6 Officially, this is not an ISO standard, however, as a generic food safety and quality management standard, it makes use of ISO 22000 and ISO 9001. For simplicity, the standard is therefore classified in this paper as ISO standard. 
7 Seventy-five percent of the processors' suppliers have a (verbal) contract, whereas $25 \%$ are cooperative members.

8 Depending on the processor: 200,000 or 300,000 instead of 400,000 white blood cells $/ \mathrm{mL}$ for somatic cell count, and 50,000 instead of 100,000 bacterial cells $/ \mathrm{mL}$ for bacterial count.

9 Tests are done for: fat, protein, somatic cell count, bacterial count, lactose, urea, free fatty acids, brucellosis, mycotoxins and antibiotics.

10 Producers receive a basic milk price per kilogram solids (a combination of fat and proteins), meaning that producers are paid more for higher sensory quality. Producers receive a bonus that gradually increases up to $18 \%$ or $19 \%$ (depending on the processor), that is contingent on higher product safety (lower bacterial values for somatic cell count and bacterial count). The payment system is partly publicly defined, but processors can tailor price bonuses to incentive quality.

11 Different institutional respondents indicated challenges of guaranteeing food safety, because the Codex Alimentarius and the National register of agrochemical products do not always overlap - which makes enforcement difficult. Since 2012, the National Residues Monitoring Plan (decree 009/ 012) is in place to apply Codex with a certain flexibility however multiple respondents indicate adoption to be in incipient stages.

12 These requirements do not always seem to be stricter than those by private quality standards, however, they do lead to additional implementation in the contract arrangement, for example, through signing codes of conduct, uploading data in monitoring systems and receiving private audits.

\section{References}

Banterle, A. and Stranieri, S. (2008), "The consequences of voluntary traceability system for supply chain relationships. An application of transaction cost economics", Food Policy, Vol. 33 No. 6, pp. 560-569, doi: 10.1016/j.foodpol.2008.06.002.

Darby, M.R. and Karni, E. (1973), "Free competition and the optimal amount of fraud", The fournal of Law and Economics, Vol. 16 No. 1, pp. 67-88, doi: 10.1086/466756.

David, R.J. and Han, S.K. (2004), "A systematic assessment of the empirical support for transaction cost economics", Strategic Management fournal, Vol. 25 No. 1, pp. 39-58, doi: 10.1002/ smj.359.

Eisenhardt, K.M. (1989), "Building theories from case study research", Academy of Management Review, Vol. 14 No. 4, pp. 532-550.

Fernández-Barcala, M., González-Díaz, M. and Raynaud, E. (2017), "Contrasting the governance of supply chains with and without geographical indications: complementarity between levels", Supply Chain Management: An International Fournal, Vol. 22 No. 4, pp. 305-320, doi: 10.1108/SCM-052016-0161.

Ghozzi, H., Soregaroli, C., Boccaletti, S. and Sauvée, L. (2016), "Impacts of non-GMO standards on poultry supply chain governance: transaction cost approach vs resourcebased view", Supply Chain Management: An International fournal, Vol. 21 No. 6, pp. 743-758, doi: 10.1108/SCM-032016-0089.

Ghozzi, H., Platoni, S., Tillie, P. and Soregaroli, C. (2018), "TCE determinants and governance forms in the EU "NonGMO” soybean supply chain", Food Policy, Vol. 78, pp. 6880, doi: 10.1016/j.foodpol.2018.02.011.

Giovannucci, D. and Reardon, T. (2001), "Understanding grades and standards and how to apply them. A guide to developing agricultural markets and agro- enterprises. Washington", available at: https://mpra.ub.uni-muenchen. de/13549/1/MPRA_paper_13549.pdf

Goertz, G. and Mahoney, J. (2012), A Tale of Two Cultures: Qualitative and Quantitative Research in the Social Sciences, Princeton University Press, Princeton, 10.23943/princeton/ 9780691149707.003.0007.

Goodhue, R.E. (2011), "Food quality: the design of incentive contracts", Annual Review of Resource Economics, Vol. 3 No. 1, pp. 119-140, doi: 10.1146/annurev-resource-040709-135037.

Groot-Kormelinck, A. and Bijman, J. (2016), "Co-innovation for quality in african food chains: Discovering integrated quality solutions", in Bijman, J. and Bitzer, V. (Eds). Quality and Innovation in Food Chains, Wageningen Academic Publishers, Wageningen, p. 274, 10.3920/978-90-8686825-4_12.

Henson, S. and Humphrey, J. (2010), "Understanding the complexities of private standards in global Agri-food chains as they impact developing countries.', The ", fournal of Development Studies, Vol. 46 No. 9, pp. 1628-1646, doi: 10.1080/00220381003706494.

Hoorani, B.H., Nair, L.B. and Gibbert, M. (2019), "Designing for impact: the effect of rigor and case study design on citations of qualitative case studies in management", Scientometrics, Vol. 121 No. 1, pp. 285-306, doi: 10.1007/s11192-019-03178-w.

Inale (2017), Situation and Perspectives of the Uruguayan Dairy Sector - 2017 (in Spanish), Montevideo, Uruguay. available at: www.inale.org/informes/2017/.

Jaffee, S., Henson, S. and Rios, L.D. (2011), "Making the grade-Smallholder farmers, emerging standards, and development assistance programs in Africa - a research program synthesis", The World Bank, Report No. 62324.

Jraisat, L.E. and Sawalha, I.H. (2013), "Quality control and supply chain management: a contextual perspective and a case study", Supply Chain Management: An International foumal, Vol. 18 No. 2, pp. 194-207, doi: 10.1108/13598541311318827.

Kataike, J., Schmidt, O. and Gellynck, X. (2019), "Measuring chain performance beyond supplier - buyer relationships in Agri-food chains", Supply Chain Management: An International fournal, Vol. 24 No. 4, pp. 484-497, doi: 10.1108/SCM-03-2018-0097.

Kirezieva, K., Jacxsens, L., Uyttendaele, M., van Boekel, M.A. J.S. and Luning, PA. (2013), "Assessment of food safety management systems in the global fresh produce chain", Food Research International, Vol. 52 No. 1, pp. 230-242, doi: 10.1016/j.foodres.2013.03.023.

Lee, J., Gereffi, G. and Beauvais, J. (2012), "Global value chains and agrifood standards: challenges and possibilities for smallholders in developing countries", Proceedings of the National Academy of Sciences, Vol. 109 No. 31, pp. 1232612331, doi: 10.1073/pnas.0913714108. 
López-Bayón, S., González-Díaz, M., Solís-Rodríguez, V. and Fernández-Barcala, M. (2018), "Governance decisions in the supply chain and quality performance: the synergistic effect of geographical indications and ownership structure", International Fournal of Production Economics, Vol. 197 No. 2017, pp. 1-12, doi: 10.1016/j.ijpe.2017.12.022.

Luning, P.A. and Marcelis, W.J. (2009), Food Quality ManagementTechnological and Managerial Principles and Practices, Wageningen Academic Publishers. Wageningen, Available at: http:// operationstech.about.com/od/glossary/g/Quality-assurance.htm.

Mena, C., Humphries, A. and Choi, T.Y. (2013), "Toward a theory of multi-tier supply chain management", fournal of Supply Chain Management, Vol. 49 No. 2, pp. 58-77, doi: 10.1111/ jscm.12003.

Menard, C. (2013), "Plural forms of organization: where do we stand", Governance of Franching Networks, c Ooperatives, and Alliances, Vol. 34 Nos 3/5, pp. 124-139.

Ménard, C. and Valceschini, E. (2005), "New institutions for governing the Agri-food industry", European Review of Agricultural Economics, Vol. 32 No. 3, pp. 421-440, doi: 10.1093/eurrag/jbi013.

Mgap (2018), "National biological residues programme. Animal and dairy chapter. (in spanish). Uruguay: ministry of agriculture and fisheries", available at: www.mgap.gub.uy/sites/default/files/ multimedia/dgsg_no_406_21_12_2018_manual_pnrb_0.pdf.

MGAP-DIEA (2018), Agricultural Statistical Yearbook (in Spanish), Montevideo, Uruguay. available at: https://descargas.mgap.gub. uy/DIEA/Anuarios/Anuario2018/Anuario_2018.pdf

MGAP-Opypa (2018), Sectoral Analysis and Production chains Annals 2018 (in Spanish), Montevideo, Uruguay. available at: www.gub.uy/ministerio-ganaderia-agricultura-pesca/comunicacion/ publicaciones/anuario-opypa-2018.

Mugwagwa, I., Bijman, J. and Trienekens, J. (2019), "Why do agribusiness firms simultaneously source from different contract farming arrangements? Evidence from the soybean industry in Malawi", International Food and Agribusiness Management Review, Vol. 22 No. 1, pp. 79-96, doi: 10.22434/ifamr2018.0079.

Pouliot, S. and Wang, H.H. (2018), "Information, incentives, and government intervention for food safety", Annual Review of Resource Economics, Vol. 10 No. 1, pp. 83-103, doi: 10.1146/annurev-resource-100516-053346.

Raynaud, E., Sauvee, L. and Valceschini, E. (2005), "Alignment between quality enforcement devices and governance structures in the agro-food vertical chains", Fournal of Management Eo Governance, Vol. 9 No. 1, pp. 4777, doi: 10.1007/s10997-005-1571-1.

Raynaud, E., Sauvee, L. and Valceschini, E. (2009), “Aligning branding strategies and governance of vertical transactions in Agri-food chains", Industrial and Corporate Change, Vol. 18 No. 5, pp. 835-868, doi: 10.1093/icc/dtp026..

Rindfleisch, A. and Heide, J.B. (1997), "Transaction cost analysis: past, present, and future applications", fournal of Marketing, Vol. 61 No. 4, pp. 30-54, doi: 10.2307/1252085.

Stranieri, S., Orsi, L. and Banterle, A. (2017), "Traceability and risks: an extended transaction cost perspective", Supply Chain Management: An International fournal, Vol. 22 No. 2, pp. 145-159, doi: 10.1108/SCM-07-2016-0268.
Trienekens, J., et al. (2012), "Transparency in complex dynamic food supply chains", Advanced Engineering Informatics, Vol. 26 No. 1, pp. 55-65, doi: 10.1016/j.aei.2011.07.007.

Trienekens, J. and Wognum, N. (2013), "Requirements of supply chain management in differentiating european pork chains", Meat Science, Vol. 95 No. 3, pp. 719-726, doi: 10.1016/j.meatsci.2013.03.035.

Trienekens, J. and Zuurbier, P. (2008), "Quality and safety standards in the food industry, developments and challenges", International Fournal of Production Economics, Vol. 113 No. 1, pp. 107-122, doi: 10.1016/j.ijpe.2007.02.050.

van der Merwe, M., Kirsten, J.F. and Trienekens, J. (2019), "Enforcement mechanisms and governance structures to protect a region of origin lamb product", Supply Chain Management: An International fournal, Vol. 24 No. 5, pp. 561-573, doi: 10.1108/SCM-01-20190026 .

Wever, M., Wognum, N., Trienekens, J. and Omta, O. (2010), "Alignment between chain quality management and chain governance in EU pork supply chains: a Transaction-Cost-Economics perspective", Meat Science, Vol. 84 No. 2, pp. 228-237, doi: 10.1016/j. meatsci.2009.05.012..

Williamson, O.E. (1985), The Economic Intstitutions of Capitalism, The Free Press, New York, NY, Available at: https:/books. google.com/books?id=MUPVLuiy9uQC\&pgis $=1$.

Williamson, O.E. (1991), "Comparative economic organization: the analysis of discrete structural alternatives", Administrative Science Quarterly, Vol. 36 No. 2, pp. 269-296, doi: $10.2307 / 2393356$..

Williamson, O.E. (2002), "Contract and economic Organization", in Brousseau, E. and Glachant, J.M. (Eds) The Economics of Contracts: Theories and Applications, Cambridge University Press, Cambridge, p. 579, 10.1111/ j.1937-5956.2009.01102.x.

Yin, R.K. (2003), Case Study Research: Design and Methods. third, CA: SAGE Publications.

Young, L.M. and Hobbs, J.E. (2002), "Vertical linkages in Agri-Food supply chains: changing roles for producers, commodity groups, and government policy", Review of Agricultural Economics. oxford university Press on Behalf of Agricultural \& Applied Economics Association, Vol. 24 No. 2, pp. 428-441, doi: 10.2307/1349770.

\section{Further readings}

Ponte, S. and Gibbon, P. (2005), "Quality standards, conventions and the governance of global value chains", Economy and Society, Vol. 34 No. 1, pp. 1-31, doi: 10.1080/ 0308514042000329315.

Reardon, T., Barrett, C.B., Berdegué, J.A. and Swinnen, J.F. M. (2009), "Agrifood industry transformation and small farmers in developing countries", World Development, Vol. 37 No. 11, pp. 1717-1727, doi: 10.1016/j.worlddev. 2008.08.023. 
Annemarie Groot-Kormelinck, Facques Trienekens and fos Bijman

\section{Appendix}

Table A1 Overview of primary and secondary data sources per topic

\begin{tabular}{|c|c|c|}
\hline Data & Dairy $(N=20)$ & Citrus $(N=19)$ \\
\hline \multicolumn{3}{|l|}{ Interviews } \\
\hline Supply chain & $\begin{array}{l}\text { Producers (2), processors (6)*, small retail (2) and } \\
\text { supermarkets (3) }\end{array}$ & $\begin{array}{l}\text { Producers (2), processors* (6), export agency (1) wholesalers (3) and small } \\
\text { retail (3) }\end{array}$ \\
\hline Institutional & $\begin{array}{l}\text { National dairy institute (5), chamber of dairy industries (1) } \\
\text { and academic researcher (1) }\end{array}$ & $\begin{array}{l}\text { Ministry of agriculture (1), technical advisors (2) and academic researcher } \\
\text { (1) }\end{array}$ \\
\hline \multicolumn{3}{|l|}{ Secondary } \\
\hline QS - public & $\begin{array}{l}\text { Laws, decrees and regulations (23) } \\
\text { Shared documents (dairy }+ \text { citrus) (32) }\end{array}$ & Laws, decrees and regulations (6) \\
\hline QS - private & Websites: ISO, HACCP and FSSC22000 & $\begin{array}{l}\text { Websites, documents: GlobalGap (3), BRC (2), Tesco Nurture (3), GRASP } \\
\text { (2), SMETA (2) and OHSAS18000 }\end{array}$ \\
\hline CA - export buyers & $\begin{array}{l}\text { Websites and documents: Nestle (6), Unilever (4), } \\
\text { FrieslandCampina (3) and Danone (1) }\end{array}$ & $\begin{array}{l}\text { Websites and documents: Walmart (4), Kroger (4), Carrefour (1) and Aldi } \\
\text { (1) }\end{array}$ \\
\hline
\end{tabular}

Figure A1 Coding rules for contract arrangement types

\begin{tabular}{|c|c|c|}
\hline & Contract arrangement & Rule \\
\hline \multirow[t]{4}{*}{ Market } & Spot market exchange & $\begin{array}{l}\text { Instant exchange of products. No commitment exists for future } \\
\text { transactions. }\end{array}$ \\
\hline & $\begin{array}{l}\text { Non-contractual } \\
\text { relationship }\end{array}$ & $\begin{array}{l}\text { Exchanges not formalized into a verbal or written contract. Exchanges } \\
\text { are often short-term and repeated. }\end{array}$ \\
\hline & Contractual relationship & $\begin{array}{l}\text { Verbal or written contract. Exchanges are repeated (short-medium } \\
\text { term), and a written commitment may exist for future transactions. }\end{array}$ \\
\hline & Equity-based contract & $\begin{array}{l}\text { An actor owns stock (and has the accompanying shareholder voting } \\
\text { rights) up to } 50 \% \text { of (one of) its suppliers/buyers. Long-term relationship. }\end{array}$ \\
\hline Hierarchy & Vertical integration & $\begin{array}{l}\text { An actor owns more than } 50 \% \text { of the stock (and has the accompanying } \\
\text { shareholder voting rights) of (one of) its suppliers/buyers. Long-term } \\
\text { relationship. }\end{array}$ \\
\hline
\end{tabular}

Sources: authors elaboration based on van der Merwe et al. (2019); and Wever et al. (2010) 
Table A2 Overview of public quality standards in dairy and citrus

\section{Dairy}

Sensory: Milk quality parameters (fat and proteins) (decree 174/002)

Safety (product): Milk safety parameters: bacterial count, somatic cell count, mycotoxins, aflatoxins, heavy metals, veterinary residues, growth hormones and other chemical products (dairy law 18.242 and decrees 174/002, 382/016, 359/013, 98/011, 915/988, 219/989, 215/013, 308/016 and 177/004)

Safety (procedures): Safe and hygienic labor practices on dairy farms (laws 13.130 and13.389), and in milk production and processing (specified per dairy product) (decree 174/002); monitoring drinking water in dairy processors (decree 62/2002); traceability (decree 174/002)

Animal welfare: Physical and sanitary norms; food and shelter; medical treatments (laws 18.471 and 18.242)

Control: Health and hygienic control of dairy processors (decree 174/002); lab control of residues in urine and dairy products (decrees $359 / 013$ and 576/009); auto-control and producer register by dairy processors (368/2000 and 65/2003); accreditation of processors and export sanitary certificates (decrees 174/002 and 159/013); Establishments of Ministry of Agriculture as sanctioning power and controller (laws 16.376 and 18.242, decree 368/00); milk quality system (decrees 359/013, 382/016 and 90/995); biological residues plan (decree 363/003); National Dairy Institute (law 18.242 and decree 393/008); veterinary medication register (resolution $193 \mathrm{~A} / 2015$ )

Citrus

Safety (product): register of agrochemical products, handled by Ministry of Agriculture (law 13.663)

Safety (procedures): occupational health and safety of producers and laborers (decree 3321/009), and in production and harvesting operations (decree 312/009)

Control: Pest control programs for citrus cancer (decree 535/003); financial support to prevent and control citrus pests and diseases (law

$\overline{16.332) ; ~ N a t i o n a l ~ R e s i d u e s ~ M o n i t o r i n g ~ P l a n ~(d e c r e e ~ 009 / 012) ~}$

Dairy + Citrus

Safety (product): microbiological, chemical and physical properties/composition of food ingredients; MRL for inorganic contaminants and biological residues for all food ingredients (e.g. for dairy mycotoxins, aflatoxins and heavy metals) (decree 315/994)

Safety (procedures: standards for safe and hygienic production, conservation, packaging, distribution (general and specified for dairy processing) (decree 315/994); safety and health of workers and working environment (decrees 291/007, 127/014 and 307/09); prevention of labor accidents (law 5.032 and decree 460/88); protective clothing and equipment (decree 103/996); exposure to chemical and physical risks (law 17.775 and decree 307/009); safety for rural workers (law 14.785 and decree 321/009) and processors (decree 406/099); labor inspection (law 14.489); work authorizations (law 15.903)

Social: labor rights: working hours (rural workers: law 18.441); company staff: law 5.350); salary (law 10.449), health insurance (law 14.407); work accidents (law 16.426); unemployment (law 18.399); dismissal (law 10.489); maternity-paternity (law 19.161); sexual harassment (law 18.561); conflict resolution (law 18.572)

Environmental: agrochemicals residue management (decree 152/013); industrial solid waste (decree 182/013); industrial packaging residues (law 17/849); industrial effluent norms and water quality parameters (decree 253/79); agricultural water use (law 16.858); protected areas (law 17.234); water protection (law 14.859); soil and water conservation (law 15.239); environmental impact law (law 16.466); environmental law (law 17.283)

Sources: Authors elaboration based on van der Merwe et al. (2019) and Wever et al. (2010) 
Annemarie Groot-Kormelinck, Facques Trienekens and Fos Bijman

Table A3 Overview of private quality standards in dairy and citrus

\begin{tabular}{l} 
Sector (adoption) \\
\hline Dairy \\
ISO $22000(100 \%)$ \\
ISO $14001(50 \%)$ \\
ISO $50001(50 \%)$ \\
FSSC $22000(50 \%)$ \\
ISO $18001(25 \%)$ \\
ISO $17025(25 \%)$ \\
Citrus \\
GlobalGap (100\%)
\end{tabular}

BRC (67\%)

Tesco Nurture (50\%)

GRASP (50\%)

SMETA $(50 \%)$

OHSAS $18000(17 \%)$

\section{Dairy and Citrus}

HACCP $(100 \%$ dairy and citrus)

ISO 9001 (75\% dairy and $34 \%$ citrus) citrus)
Safety (procedures): guidelines for a safety management system, focusing on prevention of food safety hazards and implementing HACCP

Environmental: framework for an environmental management system

Environmental: framework for an energy management system

Sensory, safety (procedures): guidelines for a generic food safety and quality management system

Social: framework to establish an occupational health and safety system

Safety (procedures): guidelines for high-quality and safe operations in lab testing

Safety (procedures): agrochemical product handling; hygiene protocols; assessments on food safety, fraud and defense; traceability and recall; record keeping of farm activities; management of varieties, sites, soil, agrochemicals, irrigation and harvesting; worker health, safety and welfare; staff training

Social: workers' rights; working conditions; complaints handling

Environmental: management of pests, irrigation, waste, pollution, energy efficiency and water collection; conservation of soil, water, biodiversity and wildlife

Safety (procedures): implementation of HACCP and management systems for food safety, quality, packaging and traceability; hygienic product and process control; site standards; staff training

Safety (procedures): producers to have agrochemical list; spray records; residue monitoring system (conduct lab residue analysis on MRL); safe agrochemical procedures

Social: implement social risk assessment system on: employee representation; complaint procedures; good social practices on human rights; documentation on contracts; working hours; pay slips; wages; records of no child labor

Social: implement ethical and social management system on freely chosen employment; freedom of association; health and

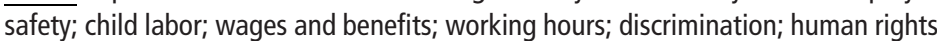

Safety (procedures): occupational health and safety management system; guidance to design occupational health and safety system

Safety (procedures): hazard analysis; determining critical control points; establishing critical limits; implementing procedures for monitoring, corrective actions, verification and record-keeping

Sensory, safety (procedures): Guidelines for a quality management system: continuous quality improvement; customers; good manufacturing practices

Sensory, safety (procedures): guidelines for a generic food safety and quality management system 
Annemarie Groot-Kormelinck, Facques Trienekens and Fos Bijman

Table A4 List of abbreviations and acronyms

\begin{tabular}{|c|c|}
\hline Abbreviation/Acronym & Meaning \\
\hline BRC & British Retail Consortium \\
\hline CA & Contract Arrangements \\
\hline FSSC & Food Safety System Certification \\
\hline GMO & Genetically Modified Organism \\
\hline GRASP & GlobalGap Risk Assessment on Social Practices \\
\hline HACCP & Hazard Analysis and Critical Control Points \\
\hline ISO & International Organization for Standardization \\
\hline MRL & Maximum Residue Levels \\
\hline OHSAS & Occupational Health and Safety Assessment Series \\
\hline QS & Quality Standards \\
\hline SMETA & Sedex Members Ethical Trade Audit \\
\hline TCE & Transaction Cost Economics \\
\hline VI & Vertical Integration \\
\hline
\end{tabular}

\section{Corresponding author}

Annemarie-Groot Kormelinck can be contacted at:

agrootkormelinck@gmail.com

For instructions on how to order reprints of this article, please visit our website:

www.emeraldgrouppublishing.com/licensing/reprints.htm

Or contact us for further details: permissions@emeraldinsight.com 